\title{
CYTOGENETIC CHARACTERISTIC OF Ovis ammon ammon, O. nivicola borealis AND THEIR HYBRIDS
}

\author{
V.A. Bagirov ${ }^{1}$, P.M. Klenovitskiy ${ }^{1}$, B.S. Iolchiev ${ }^{1}$, N.A. Zinovieva ${ }^{1}$, V.V. Kalashnikov ${ }^{2}$, \\ O.V. Shilo ${ }^{3}$, V.A. Soloshenko ${ }^{4}$, Sh.N. Nasibov ${ }^{1}$, V.P. Kononov ${ }^{1}$, A.V. Kolesnikov ${ }^{5}$ \\ ${ }^{1}$ All-Russia Research and Development Institute for Livestock Husbandry, RAAS, Dubrovitsy settlement 142132, Moscow province, Russia \\ e-mail:klenpm@mail.ru \\ ${ }^{2}$ Russian Academy of Agricultural Sciences, Moscow 117218, Russia \\ e-mail:vugarbagirov@mail.ru \\ ${ }^{3}$ Novosibirsk Zoo, Novosibirsk 630001, Russia \\ ${ }^{4}$ Siberian Research and Development, Design and Technology Institute of Livestock Breeding, RAAS, \\ Krasnoobsk settlement 630501, Novosibirsk province, Russia \\ ${ }^{5}$ Samara State Agricultural Academy, Ust-Kinelsky settlement 446442, Samara province, Russia
}

Received October 1, 2012

$\mathrm{Sum}$ m a ry

By a hybridization of wild and domestic sheep, a gene fond of sheep breeds can be enriched with useful traits, and the rare and disappearing species reconstructed. In our experiments, the hybridization between Ovis nivicola borealis and $O$. ammon ammon resulted in a reproductive offspring. The parental and hybrid animals were compared as to their karyograms which were determined on the base of ideogram for goats with addition of metacentric chromosomes. The cytogenetic data and the reproductive state of the hybrid confirm that the taxa used in hybridization are closely related.

\section{Keywords: Ovis nivicola borealis, O. ammon ammon, hybridization, karyotype.}

Sheep farming has always been an important branch of domestic agriculture. Sheep is well adapted to harsh climate of Russia, and for many centuries it has been farmed for food, wool and other specific products; in some cases sheep is the only animal species able to utilize available natural resources. Today, domestic sheep is represented by many breeds and breed groups that show a wide range of genetically determined features concerning animal morphology, productivity, and adaptability to specific conditions of breeding and farming. At present time there are approximately 850 breeds of sheep (1).

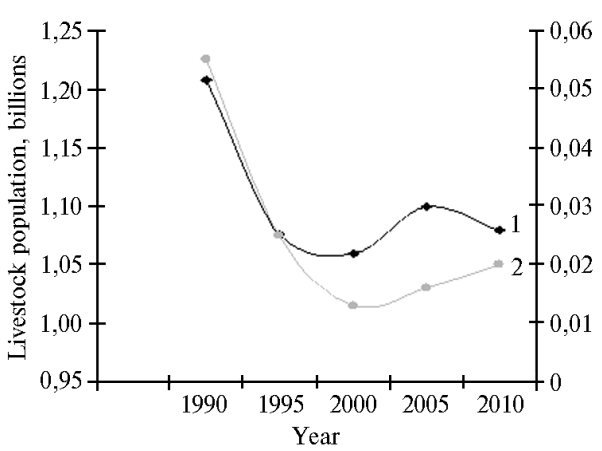

Fig. 1. Population dynamics of sheep livestock (billions heads) in the world (1, left axis) and in Russia (2, right axis).

species (4-10).

Natural habitat of wild sheep covers a vast territory of Eurasia from the Mediterranean Sea islands and Near East to Kamchatka, along with the West of North America. Animals of the genus Ovis are well adapted to different geographical regions from steppe to mountains up to the highest point at $5000 \mathrm{~m}$ above sea level (11).

The current taxonomy has no single view of the genus Ovis. The most substantiated is determining seven species of wild sheep - urial (Ovis vignei), European mouflon (O. musimon), Asian mouflon (O. orientalis), argali (O. ammon), snow sheep (O. nivicola), bighorn sheep (O. canadensis), and Dall sheep $(O$. dalli). The results of cytogenetic (12-15) and molecular genetic studies (16-19) have clearly revealed that Asian mouflon (O. orientalis) was the ancestor of domestic sheep. The presumable participation of urial and argali in domestication of sheep is contradictory to these data. European mouflon $(O$. musimon) was supposed to be the descendant of feral sheep (1). The hybrids of domestic sheep and wild species were successfully obtained by many breeders (5-7, 2023 ), but interspecific hybridization of wild sheep species is yet unknown in the available literature.

The purpose of this study was obtaining interspecific hybrids of argali (O. ammon ammon) and snow sheep (Ovis nivicola borealis) and karyotypic examination of these animals.

Technique. The hybridization was performed between a ram of snow sheep (Ovis nivicola borealis) and ewes of argali $(O$. ammon ammon). Cytogenetic analysis of the parents and hybrid offspring was performed in the 72-hour culture of peripheral lymphocytes stimulated by concanavalin A ("PanEco", Russia) at a dose of $10 \mathrm{ug} / \mathrm{ml}$. Culturing and sample preparation was carried out with a standard technique modified by the authors in respect to the experiment (24).

The obtained results were recorded using a digital video camera KC-583S ("Digital", Taiwan) and Windows-compatible software. Image processing and karyotyping were performed as previously described (25).

Results. The karyotype of ancestral Bovidae is commonly assumed as a set of 60 chromosomes including 29 pairs of uniarmed autosomes. The divergence of phylogenetic branches occurred 15-20 million years ago, and now there's a wide diversity within the family. Among the existing Bovidae, the kariotypically closest to ancestors is the genus Capra - it has monomorphic 
chromosomal set $(26,27)$.

A clearly pronounced chromosomal polymorphism is peculiar to the genus Ovis. Like all Bovidae, karyotype of Ovis demonstrates gradual evolution through centric fusions, which can be attributed to four chromosomal classes. The first class includes the only species urial $(O$. vignei), probably the "oldest" member of the genus with karyotype $2 n=58$ and one pair of metacentric chromosomes. The second class is represented by argali $(O$. ammon), whose karyotype is $2 n=56$ with two pairs of metacentric chromosomes. The third class: European mouflon $(O$. musimon), Asian mouflon (O. orientalis), bighorn sheep $(O$. canadensis $)$, Dall sheep $(O$. dalli), and domestic sheep $(O$. aries); all of them have identical karyotype $2 n=54$ with three pairs of metacentric chromosomes. The "youngest" fourth class with $2 n=52$ and four pairs of metacentric chromosomes includes the only member snow sheep $($ O. nivicola).

The first attempts to reveal similarities in chromosomes of goats and various Ovis species were performed by T.D. Bunch et al. $(28,29)$. Based on results of G-banding, T.D. Bunch firstly supposed that evolution of metacentric chromosomes in all sheep species occurred through four Robertsonian translocations corresponding to centric fusions of goat chromosomes $1 / 5^{\text {th }}, 3 / 10^{\text {th }}, 4 / 9^{\text {th }}$, and $11 / 17^{\text {th }}(29)$. Later he examined the karyotype of Severtzov's sheep (O. ammon severtzovi) (30) and identified it as a subspecies of argali. Metacentric chromosomes of argali were assumed as equivalents of the $1^{\text {st }}, 3^{\text {rd }}, 5^{\text {th }}$, and $11^{\text {th }}$ chromosomes in the ancestral Ovis karyotype.

High-resolution differential staining has revealed evolutionary rearrangements of the ancestral karyotype resulting in evolutionary divergence of Ovis species. The first pair of biarmed chromosomes in all modern sheep has evolved throuh fusion of acrocentric chromosomes, corresponding to the $1^{\text {st }}$ and $3^{\text {rd }}$ pairs of ancestral chromosomes. First this occurred in urial $(O$. vignei, $2 n=$ 58 ) and is present in all so-called "true" sheep with $2 n=56,54$ and 52. The second pair of metacentric chromosomes is the result of fusion between the $2^{\text {nd }}$ and $8^{\text {th }}$ chromosomes, which occurred in the ancestor of argali and now is peculiar to wild sheep whose $2 n=$ 56, 54 and 52. The third pair of biarmed chromosomes evolved through centric fusion between the $5^{\text {th }}$ and the $11^{\text {th }}$ chromosomes, which has led to species with $2 n=54$. This metacentric chromosome also was found in snow sheep whose karyotype is $2 n=52$; such reduction of karyotype in $O$. nivicola was caused by the fusion between the $9^{\text {th }}$ and $19^{\text {th }}$ chromosomes (31).

The study of available literature shows the lack of e cytogenetic data about wild sheep subspecies. For example, karyotype has been described in only $O$. nivicola nivicola of the seven Asian subspecies of snow sheep $(32,33)(14,34)$.

Karyotyping of parental species - argali and snow sheep, as well as hybrid progeny, wasn't possible by the means of conventional approaches, because both species have different numbers of chromosomes in a diploid set, as well as different numbers of biarmed autosomes. Considering these facts, their karyotypes were represented and described using the ideogram based on goat karyotype (base part) with the additional group of metacentric chromosomes.

A

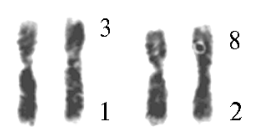

B

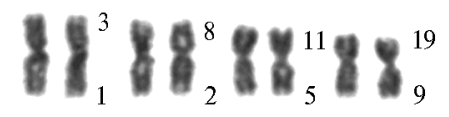

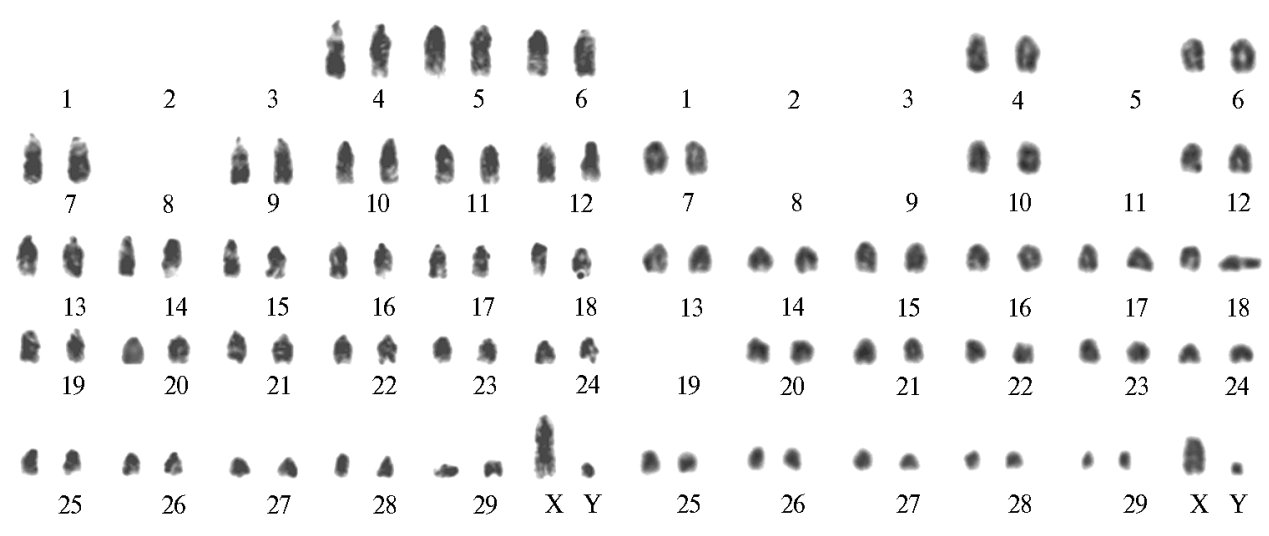

Fig. 2. Karyotypes of argali (Ovis ammon ammon) (A), snow sheep (O. nivicola borealis) $(\mathrm{B})$ and hybrid $(\mathrm{C})$ males. Selective G-banding, magnification $\times 100$.

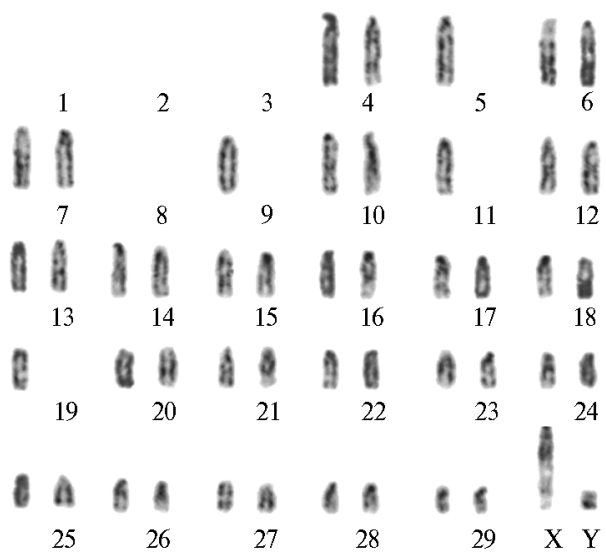

The number of chromosomes and their distribution were different in studied animal species.

In karyotype of argali (Fig. 2, A), the pairs of chromosomes 3-6 correspond to 4-7 ones of the base karyotype, and the pairs 
7-27 - to 9-29 goat chromosomes, while metacentric chromosomes - to 1/3 and 2/8 chromosomes of the base karyotype. Diploid set corresponded to the species' norm $2 n=56$.

In karyotype of snow sheep O. nivicola borealis (Fig. 2, B), $2 n=54$ similar to $O$. nivicola nivicola (35), the acrocentrics corresponded to chromosomes 4, 6, 7, 10, 12-18, and 20-29 of base karyotype, metacentric chromosomes - to 1/3, 2/8, 5/11, and 9/19 of base karyotype.

In karyotype of the hybrid argali $\times$ snow sheep (Fig. 2, C), as expected, the diploid set was $2 n=54$. Metacentric chromosomes were represented by two pairs of homologs corresponding to chromosomes $1 / 3$ and 2/8 of the base karyotype, which was inherited from both parents, and two unpaired metacentric chromosomes (5/11 and 9/19) inherited from snow sheep. Paired acrocentric chromosomes inherited from both parents, corresponded to the base chromosomes 4, 6, 7, 10, 12-18, and 29-29, unpaired acrocentric chromosomes inherited from argali - to the base chromosomes 5, 9, 11, and 19. In parental species and hybrids, the base part of ideogram showed the absence of chromosomes 1,2,3, and 8 corresponding to the metacentric chromosomes 1 and 2.

Phenotypic sex of all studied animals was consistent with chromosomal evidence. X-chromosome of argali, snow sheep and their hybrids was large acrocentric chromosome, while Y-chromosome was small metacentric.

Observation of the hybrids has shown that hybrid males of the first generation $\mathrm{F}_{1}$ were fertile, which is fairly uncommon for distant hybridization. Similar results are known in the case of hybridization of domestic sheep with Kamchatka snow sheep $O$. nivicola nivicola (35). Along with results of cytogenetic analysis, these facts suggest close relationship of these species.

Thus, experimental hybridization of argali and snow sheep has resulted in fertile hybrid offspring. Karyotyping and cytogenetic examination of the both parents and hybrids indicates close relationship of the parental species. Fertility of hybrid males is an important feature that can be used for reproduction of valuable individuals and creation of highly productive sheep populations.

\section{REFERENCES}

1. Sostoyanie vsemirnykh geneticheskikh resursov zhivotnykh v sfere prodovol'stviya i sel'skogo khozyaistva (The State of the World's Genetic Resources for Food and Agriculture), Rome-Moscow, 2010.

2. http://faostat.fao.org/default.aspx

3. Korobitsyna K.V. and Vorontsov N.N., Chromosomal Sets of Wild Sheep and Utilization of the Species' Gene Pool in Hybridization with Domestic Sheep, Biologicheskiye issledovaniya na Dal'nem Vostoke, 1975, vol. 1, pp. 135-158.

4. Bagirov V.A., Nasibov Sh.N., Klenovitsky P.M., Lesin S.A., Voevodin V.A., Zinovyeva N.A., Ernst L.K., Kalashnikov V.V., and Soloshenko V.A., Conservation and Rational Usage of Animal Gene Pool, Dokl. RASKhN, 2009, vol. 2, pp. 37-40.

5. Nasibov Sh.N., Bagirov V.A., Klenovitsky P.M., and Iolchiev B.S., Genetic Potential of Wild Fauna in Creating of New Breeding Animal Forms, Dostizheniya nauki i tekhniki APK, 2010, vol. 8, pp. 59-62.

6. Nasibov Sh.N., Bagirov V.A., Klenovitsky P.M., and Iolchiev B.S., Conservation and Rational Usage of Gene Pool of Bighorn, Dostizheniya nauki i tekhniki $A P K$, 2010, vol. 12, pp. 63-65.

7. Nasibov Sh.N., Iolchiev B.S., Klenovitsky P.M., Bagirov V.A., Voevodin V.A., and Zinovyeva N.A., Cryoconservation and Rational Use of Genetic Resources of Wild Sheep and Goats, Dostizheniya nauki i tekhniki APK, 2010, vol. 9, pp. 50-51.

8. Bagirov V.A., Gladyr E.A., Ernst L.K., Klenovitsky P.M., Zinovyeva N.A., and Nasibov Sh.N., Preservation and Efficient Use of Genetic Resources of Yak (Bos mutus), S.-kh. biol., 2009, vol. 2, pp. 37-42.

9. $\quad$ Bagirov V.A., Klenovitsky P.M., Nasibov Sh.N., Iolchiev B.S., Zinovyeva N.A., Ernst L.K., Gusev I.V., and Kononov V.P., Rational Use of Genetic Resources and Hybridization in Goat Breeding, S.-kh. biol., 2009, vol. 6, pp. 27-33.

10. The Yak, Wiener G., Jalin H., and Ruiju T.R., Eds, FAO, 2003.

11. Dankwert S.A., Kholomanov A.M., and Osadchaya O.Yu., Ovtsevodstvo stran mira (Sheep Breeding in the World), Moscow, 2010.

12. Orlov V.N. and Bulatova N.Sh., Sravnitel'naya tsitogenetika i kariosistematika mlekopitayuschikh (Comparative Cytogenetics and Caryosystematics of Mammals), Moscow, 1983.

13. Diploid Numbers Mammalian, Institute of Cytology and Genetics, SB RAS, Novosibirsk. (http://www.bionet.nsc.ru/labs/chromosomes/mammalia.htm).

14. Vorontsov N.N., Korobitsyna K.V, Nadler Ch.F., Hoffman R., Sapozhnikov G.N., and Gorelov Yu.K., Cytogenetic Differentiation of Species of Paleo-Arctic Sheep (Ovis s. str.), Zoologicheskiy zhurnal, 1972, vol. 51, no. 8, pp. 1109-1121.

15. Vorontsov N.I., Korobitsyna K.V., and Nadler Ch.F., Chromosomes of Wild Sheep and Origin of Domestic Sheep, Priroda, 1972, vol. 3, pp. 74-82.

16. Hiendleder S., Mainz K., Plante Y., and Lewalski H., Analysis of Mitochondrial DNA Indicates that Domestic Sheep are Derived from Two Different Ancestral Maternal Sources: No Evidence for Contributions from Urial and Argali Sheep, J. Hered., 1998, vol. 89, pp. 113-120.

17. Hiendleder S., Janke A., and Wassmuth R., Molecular Data on Wild Sheep Genetic Resources and Domestic Sheep Evolution, Arch. Tierz., 2001 , vol. 44 (special issue), pp. 271-279.

18. Hiendleder S., Kaupe B., Wassmuth R., and Janke A., Molecular Analysis of Wild and Domestic Sheep Questions Current Nomenclature and Provide Evidence for Domestication from Two Different Subspecies, Proc. R. Soc. Lond., 2002, vol. 269, pp. 893-904.

19. Hamid Reza Rezaei, Phylogénie Moléculaire du Genre Ovis (Mouton et Mouflons), Implications pour la Conservation du Genre et pour L'origine de L'espèce Domestique, Doct. Sci. Dissertation, Grenoble: Universite Josef Fourier, 2007.

20. Shaidullin I.N., Zhiryakov A.M., Kaplinskaya L.I., Strekozov N.I., Shikalova V.P., Sin Yu Sen, Proshkin A.V., Bin N.N., and Likhacheva G.N., Breeding MeatWool Sheep of Romanov Breed in Conditions of Kamchatka Region by the Method of Acclimatization and Hybridization with Snow Sheep Ovis nivicola nivicola, in Mat. Mezhd. Konf. "Proshloye, nastoyaschee i buduschee zootekhnicheskoy nauki” (Proc. Int. Conf. "Zootechnical Science: Past, Present, and Future"), Nauch. tr. VIZh, 2004, vol. 66, no. 1, pp. 204-215.

21. Shaidullin I.N. and Roldugin V.N., Distant Hybridization Is Possible, Ovtsevodstvo, 1986, vol. 4, pp. 40-41.

22. Ivanov M.F., Polnoe sobranie sochineniy, T. 3 (Complete Works, Vol. 3), Moscow, 1964.

23. Gikinishvili N.S., Plemennaya rabota v tsvetnom karakulevodstve (Breeding Work on Colored Karakul Sheep), Moscow, 1976.

24. Bagirov V.A., Klenovitsky P.M., Nasibov Sh.N., Iolchiev B.S., Zinovyeva N.A., and Ernst L.K., Cytogenetic Analysis when Distant Hybridizing of Cavicorn, Dostizheniya nauki i tekhniki APK, 2009, vol. 8, pp. 41-43.

25. Klenovitsky P.M., Bagirov V.A., Iolchiev B.S., and Dontsev A.V., Applied Cytogenetics of Agricultural Animals, Dostizheniya nauki i tekhniki APK, 2003, vol. 10, pp. 17-19.

26. Wurster D.H. and Benirschke K., Chromosome Studies in the Superfamily Bovoidae, Chromosoma, 1968, vol. 25, pp. 152-171.

27. Buckland R.A. and Evans H.J., Cytogenetic Aspects of Phylogeny in the Bovidae. I. G-Banding, Cytogenet. Cell. Genet., 1978, vol. 21, no. 1, pp. 42-63.

28. Bunch T.D. Fundamental Karyotype in Domestic and Wild Species of Sheep Identity and Ranking of Autosomal Acrocentrics Involved in Biarmed Formations, $J$. Hered., 1978, vol. 69, no. 2, pp. 77-80.

29. Bunch T.D., Nadler C.F., and Simmons L., G-Band Patterns, Hemoglobin, and Transferrin Types of the Bharal Chromosomal Evolutionary Relationships with Sheep and Goats, J. Hered., 1978, vol. 69, no. 5, pp. 316-320.

30. Bunch T.D., Vorontsov N.N., Lyapunova E.A., and Hoffmann R.S., Chromosome Number of Severtzov's Sheep (Ovis ammon severtzovi): G-Banded Karyotype Comparisons within Ovis, J. Hered., 1998, vol. 89, no. 3, pp. 266-269.

31. Bunch T.D., Wu C., Zhang Y.-P., and Wang S., Phylogenetic Analysis of Snow Sheep (Ovis nivicola) and Closely Related Taxa, J. Hered., 2006, vol. 97, no. 1, pp. 21-30.

32. Revin Yu.V., Sopin L.V., and Zheleznov N.K., Snezhny baran (Snow Sheep), Novosibirsk, 1988.

33. Fil V.I., Mosolov V.I., Snezhny baran Kamchatki (Snow Sheep of Kamchatka), Petropavlovsk-Kamchatsky, 2010.

34. Smirnov O.K., Zhivalev I.K., Klenovitsky P.M., and Krakasevich A.N., Karyotypic Examination of Asian Snow Sheep, Domestic Sheep, and Their Hybrids, Bul. VIZh, 1986, vol. 87, pp. 16-20.

35. Shaidullin I.N., Hybrids are Fertile, Ovtsevodstvo, 1992, vol. 3, pp. 18-21. 